\title{
INTERPRETASI KATA LOGOS DAN THEOS DALAM YOHANES 1:1
}

\author{
Yusuf L. M \\ Sekolah Tinggi Teologi Injili Setia Siau \\ Lmy38831@gmail.com
}

\begin{abstract}
Logos is Theos has always been a topic of heated discussion among Christian theologians. This subject is also often misinterpreted so that interpretations emerge that are not biblical or not following their original meaning. Logos is often accused of originating from the concept of Greek philosophy because John is considered to be much influenced by the Hellenistic world. Logos is often interpreted in the context of John 1:1 only divine, a God, or inferior to God because grammatically, the phrase "the Word is God" is assumed to provide that understanding. This phrase becomes polemic because the word Theos in the text does not use the article that can confirm the word is the same as God. Although Theos grammatically does not use the article's clothing, logos cannot be interpreted as a God, or the Logos is only divine because the third ho logos in the phrase refers to the nominative subject so that the noos becomes the predicate nominative and the article clothing is usually omitted. So if interpreted logos, it is God. This is confirmed in the first and second phrases that the logos is a person who stands alone, has his existence since eternity. He existed before the work of creation, and He is the creator, and from eternity already exists with God. Thus to answer this polemic, this study seeks to explain the concept of logos used by John and explains logos is God in the context of John 1:1 by using an interpretive analysis of words, phrases, or clauses in the text to get the correct meaning in context the original.
\end{abstract}

Keywords: Theos, Logos, John 1: 1

\begin{abstract}
Abstrak. Logos adalah Theos selalu menjadi topik bahan diskusi hangat di kalangan para teolog Kristen. Pokok ini juga sering disalahtafsirkan sehingga muncul penafsiran yang tidak alkitabiah atau tidak sesuai makna aslinya. Logos sering tuduhkan berasal dari konsep filsafat Yunani karena Yohanes dianggap banyak dipengaruhi dunia hellenistik. Logos sering ditafsirkan dalam konteks Yohanes 1:1 hanya bersifat ilahi, suatu Allah atau lebih rendah dari Allah karena secara gramatikal frasa "Firman itu adalah Allah" dianggap memberikan pengertian tersebut. Frasa ini menjadi polemik karena kata Theos di dalam teks itu tidak menggunakan kata sandang yang dapat menegaskan Firman itu adalah sama dengan Allah. Padahal, meskipun secara gramatikal Theos tidak memakai kata sandang namun logos tidak dapat diartikan sebagai suatu Allah atau Logos hanya bersifat ilahi karena ho logos yang ketiga dalam frasa tersebut menunjuk kepada subyek nominatif sehingga kata benda theos menjadi predikat nominatif dan kata sandang biasanya dihilangkan. Jadi jika diartikan logos itu adalah Allah. Hal ini dipertegas dalam frasa pertama dan kedua bahwa logos adalah pribadi yang berdiri sendiri, memiliki keberadaaanya sendiri sejak kekakalan dan dia ada sebelum karya penciptaan dan Dia sendiri adalah pencipta dan dari kekekalan sudah ada bersama-sama dengan Allah. Dengan demikian untuk menjawab polemik ini, maka penelitian ini berupaya menjelaskan konsep logos yang digunakan oleh Yohanes dan menjelaskan logos adalah Allah dalam konteks Yohanes 1:1 dengan menggunakan analisis eksegetis terhadap kata, frasa atau klausa dalam teks untuk mendapatkan pengertian dan makna yang benar sesuai konteks aslinya.
\end{abstract}

Kata kunci: Theos, Logos, Yohanes 1:1 


\section{PENDAHULUAN}

Injil Yohanes sering juga disebut sebagai Injil keempat karena Injil yang paling terakhir ditulis. Banyak hal yang sangat sulit dipahami di dalam Injil ini. Namun justru hal-hal yang sulit tersebut yang membuat Injil Yohanes sangat menarik untuk diteliti. Salah satu bagian penting yang sering diperdebatkan oleh banyak teolog adalah prolog Injil ini yakni Yohanes 1:1. Bagian yang sering diperdebatkan dalam teks tersebut adalah keberadaan $\lambda$ ó ${ }^{\circ} \varsigma$ dan $\theta \varepsilon$ òs. Dalam kaitan dengan keberadaan posisi logos sering dianggap tidak setara dengan theos. Persoalannya, dalam hal pemakaian kata sandang yang tidak dilekatkan pada kata theos di akhir kalimat dalam teks menimbulkan pemahaman bahwa logos tidak diterjemahkan Allah tetapi hanya mencerminkan sifat Ilahi atau Allah yang lebih kecil. Maksudnya seolah-olah teks mengajarkan karena tanpa article maka kata tersebut diartikan lebih rendah kedudukannya dari Allah Bapa. (Beasley-Murray 1999). Selain itu terkadang istilah logos juga dianggap tidak bisa disamakan dengan Allah karena istilah itu berasal dari dunia filsafaf Yunani khususnya dikaitkan dengan paham Stoicisme. (L. Morris 2006).

Pemahaman yang mirip dengan persoalan di atas adalah berasal dari para saksi Yehuwa. Saksi Yehuwa mengajarkan bahwa Yesus adalah suatu allah yang lebih rendah dari Yehuwa, sebagaimana yang dikatakan oleh Kitab Suci Saksi Yehuwa 'Terjemahan Dunia Baru' dalam Yohanes 1:1 yang menyatakan "Pada mulanya Firman itu ada dan Firman itu bersama Allah dan Firman itu adalah suatu allah" dan Yesus adalah ciptaan sulung yang diciptakan oleh Yehuwa, sebagaimana yang dinyatakan dalam Kolose 1:15 berbunyi: "Dia adalah gambar 
Allah yang tidak kelihatan, ciptaan yang sulung dari antara semua ciptaan" dan Wahyu 3:14 mengatakan: "Ia adalah permulaan dari ciptaan Allah". (Eliman 2018). Persoalannya, meyakini Yesus Kristus sebagai ciptaan pertama yang diciptakan oleh Allah berarti menolak bahwa Yesus Kristus sepenuhnya Allah. Doktrin Kristologi saksi Yehuwa tersebut jelas berbenturan dengan doktrin yang benar yakni mengakui Yesus sepenuhnya adalah Allah dan sepenuhnya adalah manusia. Kesaksian Alkitab juga menunjukan bahwa Yesus Kristus adalah Alfa dan Omega, Yang Awal dan Yang Akhir. (Aliyanto 2019).

Persoalan-persoalan yang dimunculkan di dalam teks Yohanes 1:1 di atas tentu sangat membutuhkan kajian yang benar terkait posisi Firman atau Logos yang dianggap tidak setara dengan Allah dan logos hanya disebut sebagai ciptaan Allah yang sulung. Pertanyaannya adalah apakah benar teks Yohanes 1:1 harus dipahami demikian? Karena itu, penelitian ini berupaya mengkaji dan menganalisis konteks Yohanes 1:1 dengan studi eksegetis terhadap kata, frasa, maupun klausa dalam teks untuk melihat secara jelas maksud teks sesuai konteks aslinya. Untuk mendapat hasil yang konprehensif dalam penelitian ini maka analisis perlu mengacu kepada beberapa garis besar isi konteks. Garis besar

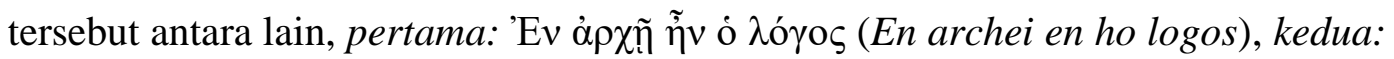

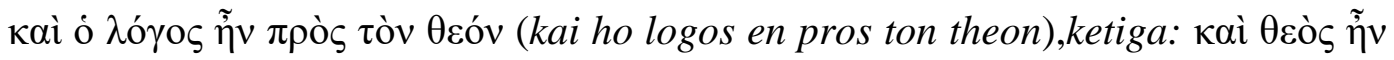
ò $\lambda$ ófos (kai theos en ho logos).

Dengan demikian, semua upaya yang dilakukan dalam analisis ini hanya bertujuan untuk menetapkan makna asli sesuai maksud penulis Injil terhadap teks, sekaligus menjawab semua tafsiran yang keliru dan klaim pengajar sesat yang 
menyatakan logos itu bukan Allah tetapi hanya bersifat Ilahi saja atau lebih rendah dari Allah.

\section{METODE PENELITIAN}

Penelitian ini merupakan kajian literatur dengan pendekatan yang digunakan adalah kualitatif dengan metode deskriptif analisis teks. Tahapan dalam analisis teks ini dimulai dari perbandingan terjemahan teks seperti terjemahan harafiah, terjemahan KJV, NAS serta terjemahan LAI (ITB) untuk lebih memperjelas arti teks asli. Setelah itu, dilanjutkan dengan analisis gramatikal disertai dengan tafsiran atas analisis gramatikal tersebut dengan menggunakan literatur yang berkaitan analisis konteks Yohanes 1:1. Hal-hal yang dideskripsikan di dalam analisis gramatikal ini yakni dengan cara melakukan kajian terhadap kata dan frasa serta klausa di dalam teks untuk menemukan pengertian dan makna yang benar sesuai maksud penulis Kitab Suci dalam konteks aslinya. (L. M 2019).

\section{HASIL PENELITIAN}

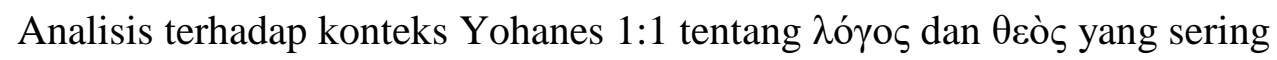
menjadi bahan perdebatan memberikan suatu penegasan bahwa tududan terhadap konsep logos yang digunakan oleh Yohanes tidak berakar di dalam filsafat Yunani meskipun istilah ini sangat umum di kenal dalam dunia Hellenistik. Dasar dari konsep logos tersebut sangat berbeda dengan konsep dunia Hellenistik karena Yohanes menjabarkan logos itu berasal atau berakar dari konsep Perjanjian Lama. Sedangkan penetapan makna teks jika dianalisis dari unsur terjemahan mulia dari 
teks asli, terjemahan LAI (ITB), terjemahan harafiah dan KJV serta NAS antara lain:

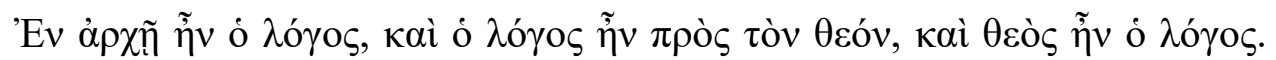
(BGT).

Pada mulanya adalah Firman; Firman itu bersama-sama dengan Allah dan Firman itu adalah Allah (ITB).

Pada permulaan adalah Firman, dan Firman adalah bersama-sama dengan Allah, dan Firman adalah Allah (harafiah)

In the beginning was the Word, and the Word was with God, and the Word was God (KJV \& NAS).

Penulis menyimpulkan bahwa LAI menerjemahkan teks Yohanes 1:1 dengan mengikuti pola terjemahan teks asli, terjemahan secara harfiah, terjemahan KJV dan terjemahan NAS. Jadi secara teknis dalam terjemahan tidak ada masalah yang dapat mengganggu atau mempengaruhi proses penetapan arti dan makna yang benar di dalam teks.

Frasa 'Ev à $\rho \tilde{\eta} \tilde{\eta} v$ ó $\lambda o ́ \gamma o \varsigma$ mengacu Kejadian 1:1 tentang karya penciptaan. Namun dalam konteksnya, frasa ini menekankan lebih jauh ke belakang dari masa peristiwa penciptaan karena Yohanes mau menjelaskan bahwa "Dia ada dan sudah ada" sebelum Allah melakukan penciptaan atau keberadaan-

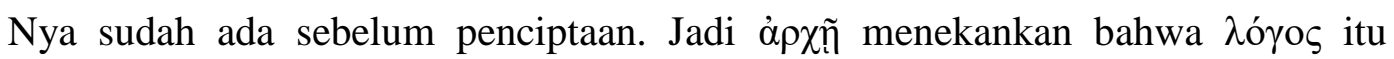
bukan bentuk pengungkapan sifat Ilahi melainkan suatu keberadaan Allah dan Dia adalah pencipta langit dan bumi.

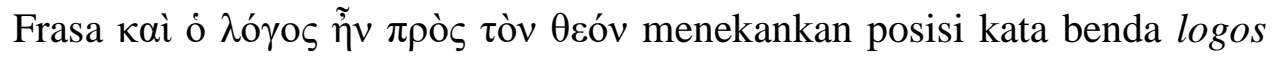
memiliki keberadaan-Nya sendiri yang kekal. Kata logos diartikan sebagai pribadi yang berdiri sendiri dan dalam keberadaanya itu logos sehakikat dengan Allah. 
Hal itu dipertegas dari penggunaan preposisi $\pi \rho \grave{\varsigma} \varsigma$ yang menekankan "searah" atau sehakikat yang tidak terpisahkan di dalam keberadaannya sejak kekekalan antara logos dan theos. Jadi logos bersama-sama dengan Allah dan Ia adalah Allah.

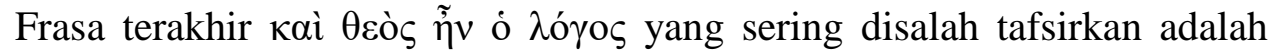
terkait kata benda theos yang tidak menggunakan kata sandang. Dalam hal ini Yohanes tetap menggunakan kata benda theos tanpa memakai kata sandang sehingga kata tersebut berbentuk predikat nominatif dan juga tidak berubah menjadi bentuk kata adjektiva atau bentuk kata subjek nominatif sebab yang

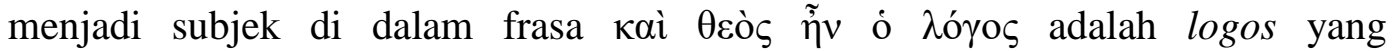
menggunakan artikel "ho" sehingga terjemahan "logos bersifat ilahi" atau logos itu adalah suatu Allah tidak benar.

Meskipun dalam bahasa Yunani memang mempunyai kata sifat tentang Allah tetapi Yohanes tidak menggunakan kata itu, dan tetap menggunakan kata benda theos dengan tidak menggunakan kata sandang tertentu di depan kata benda theos sehingga kata theos tersebut bertindak sebagai predikat nominatif dan biasanya kata benda yang tertentu kehilangan artikelnya bila berada di depan kata kerja. Alasan Yohanes adalah ia ingin menekankan bahwa logos adalah pribadi yang berbeda dengan Allah Bapa namun sehakikat yaitu Allah atau dua pribadi yang masing-masing berdiri sendiri, tetapi memiliki keberadaan yang sama yaitu Allah. Dengan demikian sangat tidak beralasan jika logos hanya dipahami bersifat ilahi dan lebih rendah dari Allah hanya karena alasan tidak memiliki kata sandang pada theos. 


\section{PEMBAHASAN}

\section{Analisis Frasa “Pada Mulanya adalah Firman" 'Ev $\dot{\alpha} \rho \chi \tilde{\eta} \tilde{\eta} v$ ó $\lambda o ́ \gamma o \varsigma$}

Pada bagian prolog Injil Yohanes ini, sangat penting untuk dipahami dengan benar mengenaikata ỏ $\rho \tilde{n}$ (archei) yang merupakan kata benda dengan kasus datif tunggal feminin yang secara harfiah berarti "permulaan". (Newman 2016). Kata ini, dapat memberi pengertian yang mengacu kepada suatu periode atau masa penciptaan dan juga mengarah kepada pengertian tentang suatu kualitas atau mutu namun bukan dalam bentuk mutu atau kualitas yang bersifat sementara. (Rienecker 1990). Artinya suatu masa atau periode dimana tidak adanya suatu batas waktu tertentu. Kata archei juga mengingatkan pada frasa "pada mulanya" yang ada di dalam Kejadian 1:1 "pada mulanya Allah menciptakan langit dan bumi”, jadi jika Kitab Kejadian memulai dengan penciptaan maka Yohanes juga mengacu kepada penciptaan tersebut. (Carson 2000). Kedua pokok penting tersebut, yakni konteks Kejadian 1:1 dan prolog Injil Yohanes dapat diartikan sebagai sesuatu yang "mutlak atau absolute" yang mengarah kepada permulaan segala benda (segala sesuatu), permulaan alam semesta (Carson 2000, 114). Namun ini tidak mengacu kepada pemahaman bahwa periode awal atau akhir keberadaan Allah karena keberadaan Allah adalah mutlak dan absolut atau tidak bersandar pada suatu periode atau masa sebab hal itu bisa mengacu pengertian keberadaan yang terbatas. (Hamilton 2001). Artinya, kata archei menunjuk kepada sesuatu yang mutlak dan merupakan awal dari segala sesuatu yang ada di dalam dunia. (H. M. Morris 2009). 
Hal ini memberi suatu penegasan bahwa Allah adalah pencipta alam semesta tidak mempunyai permulaan, artinya manusia hanya bisa berpikir sampai kepada penciptaan yakni di Kitab Kejadian dimana di dalam teks tersebut tertulis dengan jelas "pada mulanya", namun dalam hal itu, hanya bisa memberikan pemahaman yang samar-samar tentang bagaimana kehidupan atau keberadaan Allah pada diri-Nya sendiri sebelum ada waktu (bnd.17:5, 24). Maksud Yohanes dalam kata tersebut bahwa, jika ingin memulai membicarakan tentang Yesus Kristus, maka harus dimulai pada titik di mana manusia perlu menyadari bahwa dia hanya dapat mencapai batas-batas pemikiran manusiawi. (Milne 2011). Manusia tidak akan mampu untuk memahami keberadaan Allah secara utuh karena pikiran manusia sangat terbatas. Hal tersebut sangat jelas dinyatakan di

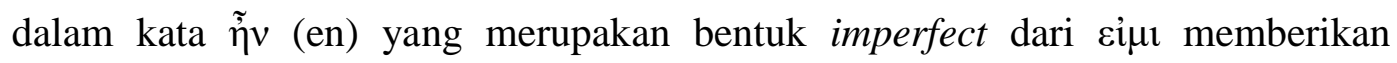
penekanan tentang keberadaan Firman yang terus berkelanjutan tanpa batas di dalam kekekalan. (Rienecker 1990). Maksudnya bahwa keberadaan $\lambda o ́ \gamma o s$ itu memang sudah ada di dalam pra-penciptaan yang tidak dibatasi oleh ruang dan

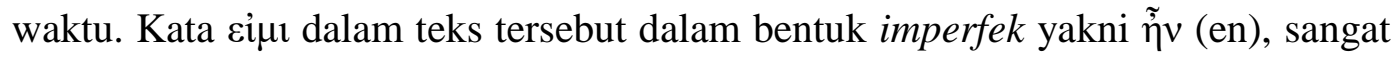

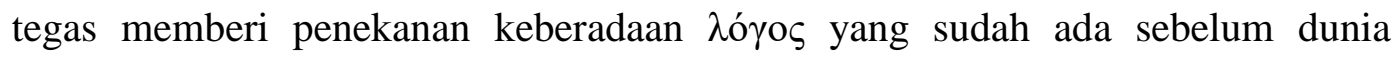
diciptakan atau sebelum ada waktu. Dalam hal ini Ridderbos menambahkan bahwa maksud kata ỏ $\rho \chi \tilde{n}$ yang menjelaskan keberadaan logos ditegaskan dalam teks dinyatakan bersama-sama dengan Allah "sebelum dunia dijadikan. (Ridderbos 2012).

Keberadaan ini dipertegas lagi setelah frasa 'Ev ả $\chi \chi \tilde{n}$ maka Yohanes

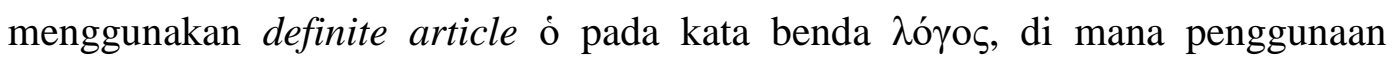


dalam article ini sangat signifikan dengan maksud penulis Injil bahwa logos adalah person yang juga adalah kreator penciptaan bersama dengan Allah Bapa seperti yang dinyakan dalam Kejadian 1. (Manurung 2016). Perbedaannya hanya terletak pada kata kerja menciptakan yang diletakkan setelah frasa in the beginning yang menjelaskan karya Allah menciptakan langit dan bumi, sedangkan Yohanes 1 meletakkan logos dalam karya penciptaan seperti yang dimaksud Kejadian 1:1 itu pada ayat 3. Namun justru di sinilah sangat jelas penekanan makna 'Ev $\grave{\rho} \rho \tilde{n}$ dalam ayat 1 lebih jauh kebelakang dari masa peristiwa penciptaan di mana Yohanes mau menjelaskan bahwa "Dia ada dan sudah ada" sebelum Allah melakukan penciptaan, sehingga Brown pun menegaskan bahwa karena keberadaanNya sudah ada sebelum penciptaan maka logos itu berada dalam lingkup penciptaan. (Brown 1996). Jadi logos adalah Allah yang juga adalah pencipta langit dan bumi (Kej.1:1).

Pertanyaan terkait apa arti $\lambda o ́ \gamma o s$, dalam hal ini memang tidak dapat hindari bahwa Yohanes menggunakan suatu konsep yang sangat khas yaitu $\lambda$ ó di mana di seluruh wilayah Kekaisaran Romawi pada abad pertama, kata $\lambda$ ó $o \varsigma$ dipakai secara luas dalam bermacam-macam konteks budaya dan filsafat. (Milne 2011). Istilah ini sudah ada jauh sebelum Rasul Yohanes menulis Injilnya, istilah tersebut sudah ada dan dipakai secara luas dalam dunia filsafat, dalam alam semesta dan juga dalam dunia agama. (Santoso 2005).

Penggunaan istilah ini, banyak teolog yang selalu berusaha memberikan

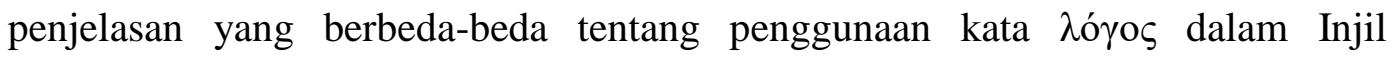
Yohanes serta berusaha untuk menjelaskan tentang latar belakang penggunaan 
kata tersebut. Ada yang menyatakan bahwa istilah $\lambda$ ó ${ }^{\circ} \varsigma$ berasal dari Stoisisme yang memahami $\lambda o ́ \gamma o \varsigma$ sebagai suatu prinsip yang rasional, selain itu sering juga ada anggapan bahwa kata $\lambda o ́ \gamma o \varsigma$ memiliki latar belakang Gnostikisme. (Carson 2000). Namun upaya untuk membantah semua anggapan itu ditegaskan melalui uraian Bruce Milne yang menjelaskan latar belakang konsep $\lambda o ́ \gamma o \varsigma$ bahwa,

Kemungkinan besar yang paling utama melatarbelakangi konsep logos itu adalah Alkitab PL dan Agama Yahudi. Akan kita lihat Yohanes berulang kali menganggap pembacanya memiliki pengetahuan dasar tentang PL. Frasa pembukaan Pada mulanya.... Berkaitan langsung dengan Kej.1:1 "pada mulanya Allah menciptakan..." perlu kita ketahui bahwa judul yang dipakai oleh orang Yahudi untuk setiap kitab dalam Kitab Suci mereka merupakan kata pertama dari setiap kitab itu. Jadi Pada mulanya adalah judul, sama seperti Kejadian. "Firman Allah adalah peranti yang dipakai Allah untuk mewujudkan tindakan penciptaan-Nya. Berfirmanlah Allah, "Jadilah terang" (Kej.1:3. Lih juga Kej.1:6, 9, 11, 14, 20, 24, 26). Firman tidak lain dari Allah sendiri dalam penciptaan-Nya yang kreatif (Milne 2011, 39-40).

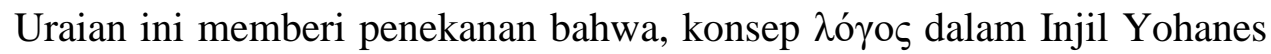
memang bukan berakar pada paham stoisisme atau gnostikisme tetapi berlatarbelakang dari Perjanjian Lama dan agama Yahudi. Meskipun demikian, konsep $\lambda o ́ \gamma o \varsigma$ memang sangat dekat dengan konsep filsafat Yunani dan hal itu mempunyai uraian sejarah yang sangat panjang sebagai contoh paling tidak sejak zaman Heraklitus (kira-kira $500 \mathrm{SM}$ ), yang menganggap logos sebagai prinsip yang membentuk, mengatur, dan mengendalikan alam semesta serta logos yang berada di balik perubahan kekal yang menjadikan dunia satu kosmos dan satu tatanan yang menyeluruh. Meski begitu, istilah $\lambda$ ó $o \varsigma$ yang ditemukan dalam literatur yakni Yohanes 1:1 dst; 1 Yoh.1:1 dan Why.19:13 dengan tegas memperlihatkan bahwa Yohanes menggunakan istilah itu yang secara luas diketahui oleh seluruh dunia Helenistik maupun Yahudi demi menyatakan Kristus 
namun Logos yang digunakan di sini sangat berbeda dengan yang dikenal dalam dunia filsafat. (Ladd 2002).

Dengan demikian frasa 'Ev $\alpha \rho \chi \tilde{n} \tilde{\eta} v$ ò $\lambda o ́ \gamma o \varsigma$ dapat disimpulkan bahwa, $\lambda$ óyos sudah ada sebelum Allah menciptakan langit dan bumi. Firman itu mendahului penciptaan. Hal ini sama seperti yang dikatakan oleh Yohanes bahwa Firman sudah ada sebelum dunia dijadikan (17:5) atau sejak semula (1 Yoh.1:1-3; 2:13-14), dalam arti Firman itu sendiri tidak ada awalnya atau Dia tidak diciptakan sebab di dalam pra-keberadaan, Firman yang meletakkan dasar bagi seluruh dunia yang diciptakan atau kreator dalam penciptaan. (Houwelingen 1997). Selain itu frasa 'Ev ả $\rho \chi \tilde{\eta} \tilde{\eta} v$ ó $\lambda o ́ \gamma o \varsigma$ juga dapat memberi penekanan maksud Yohanes yang sesungguhnya bahwa logos mempunyai keberadaannya sendiri yang kekal yaitu bersama dengan Allah atau Firman itu sepenuhnya berdiri sendiri tetapi Dia memiliki hubungan erat dengan Allah, jadi $\lambda$ ó $o \varsigma$ itu bukan bentuk pengungkapan sifat Ilahi melainkan suatu keberadaan Allah. (Houwelingen 1997). Maksudnya logos tidak diartikan hanya memiliki sifat ilahi saja melainkan Firman itu sendiri adalah Allah.

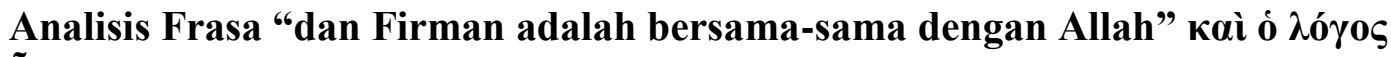

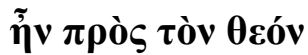

Pokok yang sangat penting dan menarik untuk dipelajari secara teliti adalah frasa tentang “dan Firman adalah bersama-sama dengan Allah”.Frasa ini dapat menimbulkan pertanyaan tentang apa yang dimaksud dengan "Firman bersama-sama dengan Allah"? untuk memahami dan mengerti dengan baik tentang frasa ini, maka perlu meneliti terlebih dahulu mengenai kata depan $\pi \rho$ ò $\varsigma$ 
yang menjelaskan tentang keberadaan kedua oknum di dalam frasa tersebut yakni Firman dan Allah.

Pada frasa kedua tersebut, kata dengan di dalam frasa itu secara harfiah dapat diterjemahkan "terhadap" yang dapat menekankan relasi. (Milne 2011). Relasi yang dimaksudkan di sini adalah suatu hubungan keberadaan Firman dengan Allah yang memiliki derajat yang sama dalam kekekalan. (Grenz 2000). Selain itu, Fritz Rienecker juga menekankan petunjuk yang sama yakni

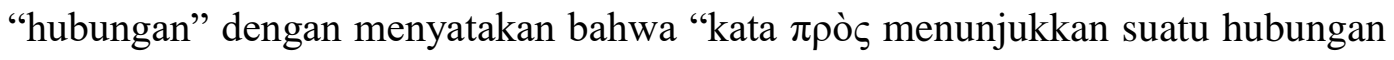
atau relasi yang akrab”. (Rienecker 1990, 217).

Hal yang sama juga ditekankan oleh beberapa teolog dengan menafsirkan proposisi $\pi \rho \grave{s}$ sebagai petunjuk adanya hubungan yang erat antara Allah dan Firman. Kata depan itu juga dapat diterjemahkan "bersama-sama" yang menyiratkan hubungan yang erat serta memiliki derajat yang sama. (Tenney 2003). Suatu hubungan atau relasi antara Firman dengan Allah. Jadi kata depan $\pi \rho o ̀ \varsigma$ di dalam teks tersebut memberikan penenakan keintiman antara Firman dan Allah.

Penekanan keintiman atau kedekatan itu sangat jelas dari kata depan $\pi \rho \grave{\varsigma} \varsigma$ yang dapat diterjemahkan "bercakap-cakap" di mana secara umum kata depan tersebut diterjemahkan "terhadap". (Carson 2000). Dari penekanan istilah "bercakap-cakap dapat memberikan penjelasan bahwa di dalam kekekalan ada dua oknum yang mempunyai relasi yang sangat dekat. Namun $\pi \rho$ ò $\varsigma$ hanya bisa diterjemahkan "bercakap-cakap" apabila ada hubungan atau relasi antar pribadi yang sangat akrab, dan hal ini sangat jelas terlihat di dalam frasa kedua yang 
menunjukkan adanya ekspresi yang sangat khas dari Yohanes yakni keintiman antara Firman dan Allah. (Carson 2000). Hal ini juga ditekankan oleh Houwelingen dengan menyatakan, bahwa "Dia ada dalam kehadiran Allah yang sangat dekat, sehingga ada hubungan pribadi dan komunikasi langsung, karena keduanya secara alami menjadi satu bagian dan saling terkait, maka sejak dahulu pun mereka juga saling bersama (1 Yoh.1:2; bnd. Mrk.6:3)”. (Houwelingen 1997,

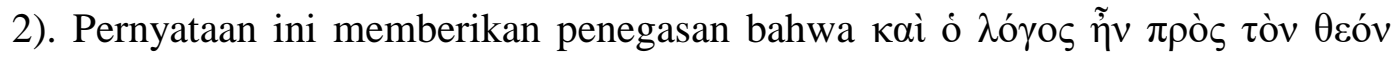
menunjukkan dua pribadi yang sangat dekat dan keduanya tidak dapat dipisahkan serta mempunyai derajat yang sama sebab kedua oknum tersebut memiliki hakikat yang sama yaitu Allah dan di dalam kekekalan, logos bersama-sama dengan Allah dan Ia adalah Allah. (Henry 1958).

Jadi dari setiap penjelasan di atas dapat disimpulkan ke dalam dua bagian yaitu, pertama: logos mempunyai keberadaan-Nya sendiri yang kekal. Logos adalah pribadi yang berdiri sendiri. Kedua: logos itu sehakikat dengan Allah. Hal itu nampak dari penggunaan preposisi $\pi \rho$ ò $\varsigma$ yang menekankan "searah" atau sehakikat yang tidak terpisahkan di dalam keberadaannya sejak kekekalan antara logos dan theos.

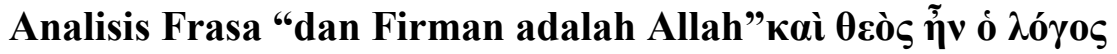

Frasa pada bagian ketiga ini, mempertegas mengenai posisi kedua pribadi di dalam teks yakni logos dan theos yang memiliki hakikat yang sama adalah Allah. Maksudnya keberadaannya bersama-sama dalam hal penciptaan, logos sebagai pribadi adalah juga pencipta karena keberadaannya sudah ada sejak 
kekekalan sebelum dunia ada. (Horton 2010). Hal ini memang sangat jelas ditekankan dalam frasa kedua yang sudah diuraikan di atas.

Namun pada frasa ketiga ini justru menimbulkan banyak perdebatan terkait dengan kata $\theta \varepsilon$ ò $\varsigma$ yang tidak menggunakan kata sandang. Frasa tersebut menimbulkan perdebatan karena kata "Allah" di sini tidak disertai kata sandang, maka terbuka jalan bagi mereka yang menyangkal keilahian Yesus Kristus untuk mengklaim bahwa terjemahan yang benar untuk kata "Allah" adalah berupa kata sifat bukan kata benda. Menurut mereka terjemahannya ialah "Firman adalah ibarat Allah" atau bukan "Ilahi, artinya Firman mencerminkan sifat-sifat Ilahi.

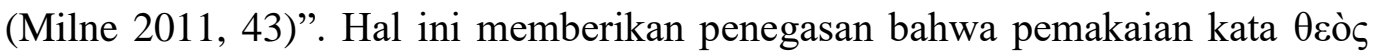
tanpa disertai dengan kata sandang dijadikan alasan oleh aliran pengajar sesat untuk menolak Firman itu adalah Allah, dan hanya mencerminkan sifat-sifat Ilahi. Seperti pendapat Moffatt yang dengan tegas mengatakan "Firman itu Ilahi" dalam pengertian bahwa logos itu sedikit lebih rendah dari Allah. (L. Morris 2006, 314).

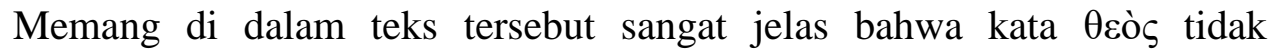
memakai kata sandang, namun hal itu justru menekankan tentang kualitas

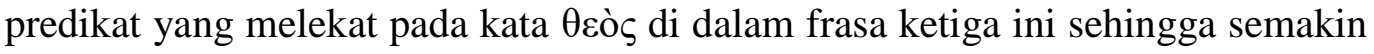
kuat penekanan natur sebagai Allah pada kata logos atau mempunyai natur yang sama dengan Allah. (Rienecker 1990). Sehingga pengertian teks tidak berbunyi bahwa Firman itu bersifat Ilahi, tetapi logos itu adalah Allah. Sebab itu di antara keduanya tidak ada kedudukan bawahan, seperti pendapat Origenes, namun yang ada ialah dua pribadi yang sama posisinya: di samping Allah, yaitu Dia yang 
dikenal $\theta \varepsilon$ ò $\varsigma$ dengan kata sandang, Dia adalah Firman itu logos dengan kata

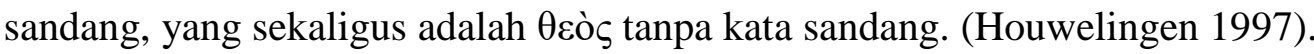

Jadi penekanan ini memberi penegasan bahwa frasa tersebut sangat jelas memberi arti bahwa Firman itu adalah Allah meskipun kata theos terakhir tidak memakai kata sandang namun justru hal itu menekankan predikat dalam kalimat bahwa logos semakin ditekankan natur-Nya bahwa Dia adalah Allah. Hal itu, sangat jelas di dalam kata $\theta \varepsilon$ ò $\varsigma \tilde{\eta} \nu$ dimana dalam struktur gramatikal bahasa Yunani kata tersebut menekankan natur Firman adalah Allah yang berasal dari kekekalan. (Wallace 1996). Tetapi meskipun ditekankan demikian, dalam menghadapi pandangan yang menyatakan bahwa Firman itu hanya bersifat Ilahi

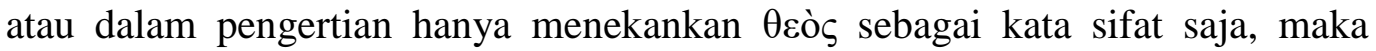
sangat penting untuk memperhatikan struktur gramatikal bahasa Yunani yang digunakan dalam teks tersebut. Sebenarnya secara gramatikal dalam tata bahasa Yunani, kata benda $\theta \varepsilon$ ò $\varsigma$ di dalam teks itu tidak berubah menjadi kata sifat meskipun tidak ada kata sandangnya namun kata tersebut tetap sama artinya

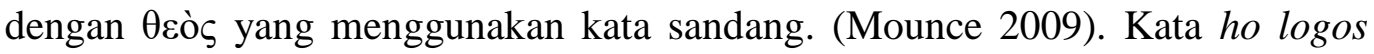
yang ketiga dalam frasa tersebut menunjuk kepada subyek sehingga $\theta$ cò predikat dan kata sandangnya biasanya dihilangkan seperti beberapa teks dalam Perjanjian Baru, di mana kata benda predikat tidak mempunyai kata sandang

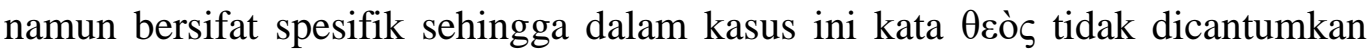
kata sandang. Bahkan dalam bahasa asli pasal ini "Engkau Raja orang Israel" (1:49), tidak mempunyai kata sandang sebelumnya "Raja" lihat juga 8:39; 17:17; Rm.14:17; Gal.4;25; Why.1;20. Sebenarnya kalau Yohanes memasukkan 
suatu kata sandang berarti ia mengatakan sesuatu yang tidak benar. Sebab jika sebuah predikat ditempatkan di depan kata kerja, maka predikat itu kehilangan kata sandangnya. Para ahli bahasa Yunani menyatakan bahwa masalah gramatikal ini telah diselidiki dengan benar, dan hasil dari penyelidikan itu dapat disimpulkan bahwa terjemahan tradisionalnya dinyatakan sepenuhnya benar. (Houwelingen 1997). Bahkan van Houwelingen menambahkan bahwa "jika seandainya di dalam teks tersebut yang tertulis ialah "ho theos en ho logos, maka jelas terjadi pertentangan dalam naskah karena pasti terjadi perbedaan antara Ocòs yang memakai kata sandang dengan logos yang memakai kata sandang menjadi dua pribadi yang saling berbeda." (Houwelingen 1997, 3). Hal yang sama ditekankan oleh Colwell bahwa "kata benda yang tertentu (Inggris: definite noun) kehilangan artikelnya bila ada di depan kata kerja” (L. Morris 2006). Memang secara gramatikal di dalam teks tersebut terdapat satu kata benda yang memiliki artikel, maka kata benda tersebut menjadi subjek kalimat itu, sedangkan yang kata benda tanpa artikel bertindak sebagai predikatnya. Sebab itu berdasarkan kaidah tersebut maka kata logos dalam frasa tersebut merupakan subjek nominatif karena memiliki artikel ho sedangkan kata theos merupakan predikat nominative karena tidak memiliki artikel. Dengan demikian terjemahan baru Alkitab sudah tepat menerjemahkannya menjadi "Firman itu adalah Allah dan KJV “the Word was God”. (Gunawan 2019).

Dalam hal ini, Yohanes meniadakan kata sandangnya karena pada bagian awal yakni 1:1a dan 1:1b ia sudah membedakan antara Allah dan Firman dan kemudian pada frasa terakhir di dalam konteks tersebut dia hendak menunjukkan 
persamaan keberadaan antara Allah dan Firman. Artinya Yohanes dengan teliti ingin menunjukkan kepada pembacanya bahwa di satu pihak Firman dan Allah adalah dua pribadi yang mempunyai relasi yang sangat erat di dalam kekekalan, dan di pihak lain dia ingin menunjukkan bahwa Firman itu memiliki keberadaan yang sama dengan Allah. Ridderbos mempertegas pokok ini dengan menyatakan bahwa keberadaan Firman itu dapat dianggap sangat unik dan Dia dinyatakan tinggal bersama-sama dengan Allah, suatu eksistensi yang tidak tumpang tindih dan Firman itu sendiri adalah Allah. (Ridderbos 2012).

Oleh karena itu, terjemahan-terjemahan seperti "Firman itu bersifat Ilahi" seperti yang ditafsirkan oleh Unitarianisme atau "Firman itu adalah suatu Allah" seperti yang ditafsirkan oleh saksi Yehova dapat dinyatakan tidak benar sebab jika dipahami demikian maka kata theos tanpa artikel ini seolah olah berbentuk subjek nominative atau berbentuk adjektiva. (Gunawan 2019). Lagi pula dalam bahasa Yunani memang mempunyai kata sifat untuk "ilahi" yaitu theios. Jadi jika Yohanes hendak mengatakan Firman itu bersifat Ilahi maka Yohanes tidak akan menggunakan kata theos melainkan kata theios. Namun di dalam teks tetap menggunakan theos tanpa definite article dalam bentuk predikat nominative sebab ia mau menunjukkan bahwa pada dasarnya tidak ada perbedaan dalam hakikat antara theos dan logos, kedua pribadi itu sama adalah Allah (Milne 2011).

Jadi bagian ketiga ini memberikan dua hal penting yang perlu untuk dipahami dan dimengerti dengan benar adalah pertama: bahwa di dalam teks 1:1c, Yohanes tetap menggunakan kata benda theos tanpa kata sandang tertentu 
(definite article) dalam bentuk predikat nominatif dan tidak menggunakan kata sifat sehingga terjemahan "Firman itu bersifat ilahi" atau Firman suatu Allah tidak benar. Kedua: Yohanes tidak menggunakan kata sandang tertentu di depan kata theos sehingga kata theos berbentuk predikat nominative. Tujuannya untuk menekankan bahwa logos adalah pribadi yang berbeda dengan Allah Bapa namun sehakikat yaitu Allah atau dua pribadi yang berdiri sendiri tetapi memiliki keberadaan yang sama yaitu Allah.

\section{KESIMPULAN}

Setelah meneliti konteks Yohanes 1:1, maka penulis menyimpulkan maksud dari teks tersebut ke dalam tiga bagian yaitu: Pertama: penekanan makna 'Ev à $\chi \tilde{n ̃ ~ d a l a m ~ d a l a m ~ f r a s a ~ p e r t a m a ~ i n i ~ m e m b e r i ~ a r t i ~ l e b i h ~ j a u h ~ k e b e l a k a n g ~ d a r i ~}$ masa peristiwa penciptaan dimana Yohanes mau menjelaskan bahwa "Dia ada dan sudah ada" sebelum Allah melakukan penciptaan atau keberadaanNya sudah ada sebelum penciptaan. $\lambda o ́ \gamma o \varsigma$ itu bukan bentuk pengungkapan sifat Ilahi melainkan suatu keberadaan Allah. Jadi logos adalah Allah yang juga menjadi pencipta langit dan bumi.

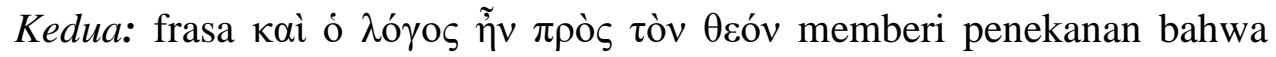
logos mempunyai keberadaan-Nya sendiri yang kekal. Logos adalah pribadi yang berdiri sendiri dan dalam keberadaanya itu logos sehakikat dengan Allah. Hal itu nampak dari penggunaan preposisi $\pi \rho \grave{\varsigma} \varsigma$ yang menekankan "searah" atau sehakikat yang tidak terpisahkan di dalam keberadaannya sejak kekekalan antara logos dan theos. Jadi logos bersama-sama dengan Allah dan Ia adalah Allah. 
Ketiga: Teks 1:1c, Yohanes tetap menggunakan kata benda theos tanpa kata sandang tertentu (definite article) dalam bentuk predikat nominatif dan tidak menggunakan kata sifat di dalam teks sehingga terjemahan"Firman itu bersifat ilahi"atau "Firman itu suatu Allah" dinyatakan keliru karena tidak sesuai terjemahan gramatikal yang benar karena kata theos itu tidak berbentuk subjek nominatif karena subjek dalam konteks ini adalah logos sebab memilik artikel "ho" namun juga tidak berbentuk adjektiva. Alasannya Yohanes tidak menggunakan kata sandang tertentu di depan kata theos sehingga kata theos tersebut bertindak sebagai predikat nominatif sebab ia ingin menekankan bahwa logos adalah pribadi yang berbeda dengan Allah Bapa namun sehakikat yaitu Allah atau dua pribadi yang masing-masing berdiri sendiri, tetapi memiliki keberadaan yang sama yaitu Allah.

\section{DAFTAR PUSTAKA}

Aliyanto, Deky Nofa. 2019. "Tanggapan Terhadap Kristologi Saksi Yehuwa Kristus adalah Ciptaan Yang Pertama Berdasarkan Kolose 1:15." FIDEI: Jurnal Teologi Sistematika dan Praktika 2 (2): 244-361. https://doi.org/10.34081/fidei.v2i2.39.

Beasley-Murray, George R. 1999. Word Biblical Commentary: John. 2nd ed. Nelson Reference \& Electronic, A Division of Thomas Nelson Publisher.

Brown, Raymond. E. 1996. Gospel According to John. New York: Doubleday.

Carson, D. A. 2000. The Gospel According to John (The Pilar New Testament Commentary). Grand Rapids: William B. Eerdman Publishing Company.

Eliman, Eliman. 2018. "Kritik dan Analisa Terhadap Pandangan Saksi Yehuwa Tentang Keilahian Yesus." Kurios $3 \quad$ (1): 22. https://doi.org/10.30995/kur.v3i1.26.

Grenz, Stanley J. 2000. Theology for the Community of God. Michigan: William B. Eerdman Publishing Company. 
Gunawan, Samuel T. 2019. "LOGOS ADALAH ALLAH: SEBUAH EKSEGESIS DAN ANALISIS TEOLOGIS ATAS YOHANES 1:1.” Teologia Reformed. 2019. https://teologiareformed.blogspot.com/2020/ 01/logos-adalah-allah-sebuah-eksegesis-dan.html.

Hamilton, Victor P. 2001. The Book Of Genesis Chapter 1-17. Grand Rapid, Michigan: Eerdmans Publishing Company.

Henry, Alford. 1958. The Greek New Testament. Chicago: Moody Publisher.

Horton, Michael. 2010. The Christian Faith. Grand Rapid, Michigan: Zondervan.

Houwelingen, P.H.R. Van. 1997. Johannes Het Evangelie van het Woord (Yohanes. Injil Firman). Kampen: Kok.

L. M, Yusuf. 2019. "MAKNA DIALOG YESUS DENGAN FILIPUS DALAM YOHANES 14: 8-14." VISIO DEI: JURNAL TEOLOGI KRISTEN 1 (2): 239-58. https://doi.org/10.35909/visiodei.v1i2.39.

Ladd, George Eldon. 2002. Teologi Perjanjian Baru Jilid 1. Bandung: Kalam Hidup. https://www.kalamhidup.com/product/teologi-perjanjian-baru-jilid-1/.

Manurung, Pangeran. 2016. "Studi Eksegetis Yohanes 1:1-18 Sebagai Apologetik Terhadap Kristologi Saksi Yehuwa." Journal Kerusso 1 (2): 1-41. https://doi.org/10.33856/kerusso.v1i2.49.

Milne, Bruce. 2011. Seri Pemahaman dan Penerapan Amanat Alkitab Masa Kini: YOHANES “Lihatlah Rajamu”,. Jakarta: YKBK.

Morris, Henry M. 2009. The Genesis Record. Grand Rapid, Michigan: Baker Book House.

Morris, Leon. 2006. Teologi Perjanjian Baru. Malang: Gandum Mas.

Mounce, William D. 2009. Basics of Biblical Greek. Grand Rapid, Michigan: Zondervan.

Newman, B. M. 2016. Kamus Yunani - Indonesia: Untuk Perjanjian Baru. 22 ed. Jakarta: BPK Gunung Mulia.

Ridderbos, Herman N. 2012. Injil Yohanes: Suatu Tafsiran Theologis. Surabaya: Momentum.

Rienecker, Fritz. 1990. A Linguistik Key to the Greek New Testament. Grand Rapids, Michigan: Zondervan Publishing House.

Santoso, David Iman. 2005. Teologi Yohanes: Intisari dan Aplikasi. Malang: Literatur SAAT. 
BONAFIDE: Jurnal Teologi dan Pendidikan Kristen

www.jurnal.sttissiau.ac.id/Volume 1/Nomor 1/Juni 2020/hal. 23-43

Tenney, Merrill C. 2003. Injil iman: Suatu telaah naskah injil Yohanes secara analitis. Yayasan penerbit gandum mas.

Wallace, Daniel B. 1996. Greek Grammer Beyond the Basics an Exegetical Syntax of the New Testament. Grand Rapid, Michigan: Zondervan. 